\title{
Transfusão Sangüínea em Crianças e os Métodos para Evitá-la: Uma Reavaliação *
}

\section{Blood Transfusion in Pediatric Patients and Strategies to Decrease it: A Reevaluation}

Mário José da Conceição, TSA ${ }^{1}$

\section{RESUMO}

Conceição MJ - Transfusão Sangüínea em Crianças e os Métodos para Evitá-la: Uma Reavaliação

JUSTIFICATIVA E OBJETIVOS: Muitas medidas e técnicas são utilizadas, nos pacientes adultos, na tentativa de reduzir, ou evitar, tanto a perda sangüínea como a administração de sangue homólogo durante atos cirúrgicos para os quais se esperam grandes perdas na volemia. Enquanto as estratégias para evitar a utilização de sangue homólogo em pacientes adultos são largamente empregadas, nos pacientes pediátricos são negligenciadas. Talvez isso se deva ao fato de que em crianças essas técnicas podem não ser tão úteis quanto nos adultos, além dos problemas técnicos próprios do tamanho dos pacientes. O objetivo dessa revisão foi reavaliar as técnicas para reduzir a necessidade de transfusão de sangue homólogo em adultos e discutir sua utilização em pacientes pediátricos.

CONTEÚDO: Através da pesquisa bibliográfica apresentam-se às estratégias mais freqüentes para diminuir, ou mesmo evitar, transfusão de sangue homólogo durante atos cirúrgicos nos quais esperam-se grandes perdas volêmicas. Como todos os métodos conhecidos foram desenvolvidos para pacientes adultos, projeta-se, a partir daí, reavaliando-se esses métodos, técnicas e fármacos, uma linha de ação visando a sua aplicabilidade nos pacientes pediátricos.

CONCLUSÕES: Mais uma vez fica patente que as soluções obtidas para adultos não são aplicáveis inteiramente aos pacientes pediátricos. As medidas para reduzir o sangramento intra-operatório e a conseqüente redução na necessidade do emprego de sangue homólogo são eficientes em pacientes adultos, porém são de longe mais invasivas, complicadas e muitas delas ineficientes nos pacientes pediátricos, notadamente naqueles abaixo de dois anos de idade.

Unitermos: ANESTESIA, Pediátrica; DROGAS: antifibrinolíticos; SANGUE: hemodiluição, transfusão

\footnotetext{
* Recebido do (Received from) Serviço de Anestesiologia do Hospital Infantil Joana de Gusmão - CET integrado da SES-SC - Florianópolis

1. Professor de Anestesiologia, Curso de Medicina, Fundação Universidade Regional de Blumenau, SC
}

Apresentado (Submitted) em 14 de abril de 2003

Aceito (Accepted) para publicação em 01 de julho de 2003

Endereço para correspondência (Correspondence to)

Dr. Mário José da Conceição

Rua Germano Wendhausen, 32/401

88015-460 Florianópolis, SC

E-mail: marioconceição@uol.com.br

(C) Sociedade Brasileira de Anestesiologia, 2004

\section{SUMMARY}

Conceição MJ - Blood Transfusion in Pediatric Patients and Strategies to Decrease it: A Reevaluation

BACKGROUND AND OBJECTIVES: Several approaches and techniques are used in adult patients to decrease or prevent both blood loss and homologous blood transfusion during surgical procedures where massive blood losses are expected. While these blood-sparing strategies are widely used in adults, they are mostly neglected in children. Perhaps in pediatric patients, these blood-sparing techniques may not be as effective as in adults and technical limitations, as the small size of patients could limit its advantages. In the following review, blood-sparing techniques established for adults are described and their applicability in pediatric patients discussed.

CONTENTS: Blood-sparing strategies developed for adult patients aiming at decreasing or even preventing homologous blood transfusion when massive blood losses are expected, are presented through a bibliographic review. Since all known methods were developed for adult patients, an action line was drawn for the reevaluation of these methods, techniques and drugs to be used in pediatric patients.

CONCLUSIONS: It has become once more clear that solutions for adult patients may not be as effective for pediatric patients. Intraoperative blood-sparing techniques and consequent decrease in the need for homologous blood are effective for adult patients but are by far more invasive, complicated, and some of them ineffective in pediatric patients, especially those under two years of age.

Key Words: ANESTHESIA: Pediatric; BLOOD: hemodilution, transfusion; DRUGS: antifibrinolytics

\section{INTRODUÇÃO}

$\mathrm{M}$ uitas medidas e técnicas são utilizadas nos pacientes adultos, na tentativa de reduzir, ou evitar, tanto a perda sangüínea como a administração de sangue homólogo durante atos cirúrgicos para os quais se esperam grandes perdas da volemia ${ }^{1-3}$. Os próprios pacientes estão, em sua maioria, informados sobre os efeitos adversos da transfusão sangüínea, principalmente, após o advento do risco da contaminação pelo vírus da imunodeficiência humana (HIV). Existe ainda problema relacionado à fé religiosa, como no caso das Testemunhas de Jeová. Enquanto as estratégias para evitar a utilização de sangue homólogo em pacientes adultos são largamente empregadas, nos pacientes pediátricos são negligenciadas, a julgar pela parca literatura envolvendo o tema. Talvez isso se deva ao fato de que em crianças essas técnicas podem não ser tão úteis quanto nos adultos, além dos problemas técnicos próprios do tamanho dos pacientes. Porém algumas estratégias podem ser utilizadas, baseadas nas experiências com pacien- 
tes adultos, para reduzir, ou mesmo evitar, a utilização de sangue homólogo em certos tipos de cirurgias pediátricas, cujos pacientes sejam de antemão selecionados e as indicações definidas de forma adequada. Nesta revisão as técnicas para reduzir a necessidade de transfusão de sangue homólogo em adultos são reavaliadas e sua utilização em pacientes pediátricos discutida.

\section{AUTODOAÇÃO PRÉ-OPERATÓRIA}

Até o momento, a técnica mais aceita para reduzir ou eliminar os riscos de uma transfusão de sangue homólogo é a doação pré-operatória de sangue autólogo, seguida ou não de hemodiluição ${ }^{4}$. Se para pacientes adultos essa prática encontra bons fundamentos científicos e utilidade prática, nos pacientes pediátricos há uma série de fatores complicadores, que aumentam os riscos, que podem ser assim descritos:

1. Crianças podem necessitar de sedação ou de anestesia para a doação. Diante disso, talvez anestésicos inalatórios sejam preferíveis. Propofol, tiopental, opióides deveriam ser evitados pois podem desencadear efeitos adversos quando o sangue for re-transfundido;

2. Bolsas de coleta devem ser especiais, de menor volume, pois as tradicionais possuem solução anticoagulante projetada para grandes volumes adultos, o que será excessivo para os pequenos volumes pediátricos;

3. Os problemas com o acesso venoso podem impedir a autodoação numa série de pacientes pediátricos, cuja punção venosa com agulhas de calibre adequado para a retirada do sangue será problemática ${ }^{5}$.

Apesar desses fatores complicadores, muitos defendem a autotransfusão em crianças, por acreditarem que os benefícios sobrepujam os riscos e problemas já mencionados. Todavia, em virtude da complexidade da autodoação em crianças, essa deveria ser indicada apenas para pacientes acima de $20 \mathrm{~kg}$ e nos quais se esperam grandes volumes de sangramento intra-operatório ${ }^{5}$.

\section{HEMODILUIÇÃO}

Nos pacientes pediátricos, a hemodiluição, em termos teóricos, é muito mais fácil de ser realizada do que a autodoação pré-operatória. Porém, Bryson e col. ${ }^{6}$ em recente estudo, através de meta-análise, mostraram que a hemodiluição intra-operatória não reduziu a necessidade da utilização de sangue homólogo. Ainda segundo os mesmos autores, muitos trabalhos incluídos na meta-análise não levaram em consideração princípios básicos para a hemodiluição, tais como: hematócrito inicial acima de 35\% e hematócrito mínimo tolerado abaixo de $25 \%$. Se esses critérios forem desconsiderados, o volume de sangue retirado será insuficiente para estabelecer uma diferença com relação à necessidade do uso de sangue homólogo. Em crianças, na grande maioria das vezes, esses critérios não podem ser empregados. Em primeiro lugar, em lactentes até seis meses de idade a hemodilui- ção está contra-indicada em virtude da alta concentração da hemoglobina fetal. Como se sabe, a hemoglobina fetal desvia a curva da oxihemoglobina para a esquerda, limitando a disponibilidade de oxigênio para o território tecidual. Hematócritos baixos, nessa situação, podem conduzir a estado de hipóxia e/ou isquemia tecidual. Acima dos seis meses, até um ano de idade, ocorrerá a chamada "anemia fisiológica" de novo contra-indicando hematócritos muito baixos pelos mesmos motivos. Dessa forma, a hemodiluição só deverá ser empregada em crianças acima de um ano da idade. Apesar de inexistirem muitos estudos, em crianças, nessa área, para comprovar a eficácia e discutir os possíveis problemas como em adultos ${ }^{6}$.

\section{AUTOTRANSFUSÃO INTRA-OPERATÓRIA}

Apesar dos bons resultados obtidos em pacientes adultos com as técnicas de autotransfusão intra-operatória, reduzindo as perdas e diminuindo a necessidade de transfusão de sangue homólogo, não podemos aplicar essa técnica diretamente ao paciente pediátrico ${ }^{8}$.

Aquantidade de sangue "perdida" é quase sempre muito pequena para ser coletada, apesar de ser grande para a volemia dos pacientes. Muitas vezes o sangue não chega nem a ser aspirado, pois já foi absorvido por compressas, campos cirúrgicos ou as próprias luvas dos cirurgiões. Mesmo que as compressas sejam lavadas com solução fisiológica, pelo menos $50 \%$ do volume sangüíneo contido se perde. Para que a máquina de autotransfusão possa funcionar adequadamente, torna-se necessário um volume mínimo de sangue a ser lavado e re-transfundido. Esse volume é mais ou menos de $300 \mathrm{ml}$; o que pode significar bem mais da metade da volemia de um paciente com $20 \mathrm{~kg}$. Crianças abaixo desse peso seguramente não tolerarão uma perda de $300 \mathrm{ml}$ de sua volemia, sem receber sangue homólogo ${ }^{9}$. Todavia, crianças acima dos $20 \mathrm{~kg}$ podem tolerar perdas como essa. Nesses pacientes, técnicas de autotransfusão podem ser úteis. Mas um outro problema pode ser levantado: qual o hematócrito mínimo considerado "seguro" para o paciente pediátrico? Amaioria dos anestesiologistas pediátricos, especialistas, não permite hematócrito abaixo de $30 \%$, principalmente em pacientes abaixo de um ano de idade e pelos motivos discutidos anteriormente, ao contrário dos pacientes adultos, ou crianças com peso acima dos $30 \mathrm{~kg}$, quando se pode trabalhar com valores bem abaixo desse. Entretanto, outros autores sugerem trabalhar com hematócritos tão baixos quanto $17 \%$ em pacientes com pesos variando entre 11 e $23 \mathrm{~kg}$, sem problemas com a oxigenação tecidual ${ }^{10}$. Para esses autores, perdas maiores podem ser toleradas, sem a necessidade de sangue homólogo, mesmo para pacientes com peso inferior a $20 \mathrm{~kg}$ 10,11. Existem já disponíveis máquinas para autotransfusão em pacientes pediátricos, porém com desvantagens ainda não solucionadas pela tecnologia ${ }^{12}$. Um desses equipamentos tentou resolver o problema com uma capacidade menor do recipiente para o sangue drenado do campo cirúrgico, permitindo o funcionamento do equipamento com $100 \mathrm{ml}$ de sangue. O problema é que muitas vezes o recipiente não é to- 
talmente completado e uma unidade de sangue autólogo com qualidade e hematócrito imprevisíveis é administrada. Um outro aparelho é o equipamento de autotransfusão contínua que eliminou o recipiente para o sangue drenado do campo operatório. O sangue drenado é bombeado para uma câmara de separação com capacidade de até $30 \mathrm{ml}$, enquanto solução fisiológica a $0,9 \%$ é adicionada para lavagem. Esse equipamento permite processar volumes de sangue inferiores a $100 \mathrm{ml}$, e autotransfusão em pacientes com menos de $10 \mathrm{~kg}$.

Em cirurgia cardíaca com circulação extracorpórea (CEC) pode-se re-transfundir parte do sangue que permaneceu no circuito da máquina de CEC, após filtração, diminuindo-se a necessidade de sangue homólogo ${ }^{13}$.

Uma solução simples seria a re-transfusão diretamente do sangue drenado do campo cirúrgico sem lavá-lo. Porém a re-transfusão de sangue não-lavado ativa o sistema fibrinolítico, com conseqüente fibrinólise e aumento da perda sangüínea ${ }^{14}$.

\section{DESMOPRESSINA}

O fator de von Willebrand é fundamental no início do processo de formação do coágulo, favorecendo a adesividade das plaquetas às regiões lesadas no endotélio vascular. A desmopressina favorece a liberação do fator de von Willebrand dos estoques endoteliais e aumenta a expressão dos receptores glicoprotéicos na superfície plaquetária. Dessa forma a adesividade das plaquetas às regiões danificadas do endotélio é incrementada. A dose normalmente é de $0,3 \mu \mathrm{g} \cdot \mathrm{kg}^{-1}$. Inicialmente seu emprego foi pós-circulação extracorpórea, com a finalidade de reduzir o sangramento e melhorar a coagulabilidade do sangue,. Ela vem sendo utilizada também profilaticamente em cirurgias de grande porte, em que se esperam grandes perdas, com a mesma finalidade ${ }^{15}$. Entretanto, seu uso em adultos vem cercado de grande controvérsia. Nos pacientes pediátricos, o uso da desmopressina também não acrescenta nenhuma vantagem ${ }^{16}$. Não só não interfere com a perda sangüínea, como a dosagem do fator de von Willebrand em estudos controlados foi a mesma em pacientes nos quais havia, ou não, administração de desmopressina ${ }^{17}$. Pacientes pediátricos não aumentam a quantidade de fator de von Willebrand liberado dos estoques após o uso da desmopressina ${ }^{17}$. Parece que o fato relaciona-se com o próprio ato cirúrgico, cujo estímulo libera o fator de von Willebrand de forma máxima, de tal forma que liberações extras inexistem com o uso da desmopressina.

\section{ANTIFIBRINOLÍTICOS}

Em nossos dias, agentes antifibrinolíticos são usados de forma profilática com a intenção de reduzir o sangramento intra-operatório em pacientes submetidos à cirurgias com CEC $^{18,19}$. Alguns estudos mostram redução significativa na perda sangüínea quando é utilizada a aprotinina ou análogos da lisina (ácidos tranexâmico e epsilon-amino-capróico) ${ }^{20}$. Esses estudos todavia foram realizados com pacientes adul- tos submetidos à cirurgia cardíaca com CEC. Durante a CEC, de fato, ocorre uma ativação anormal dos sistemas de coagulação e fibrinólise. A coagulação é evitada com a heparinização, porém a fibrinólise é negligenciada. Como durante a CEC existe a estimulação do fator ativador do plasminogênio, inicia-se a fibrinólise com aumento do sangramento. Nos pacientes pediátricos isso parece funcionar de forma diversa ${ }^{21}$. O equilíbrio entre coagulação e fibrinólise é mais instável e sujeito à estimulação exógena. A hemostasia nos pacientes pediátricos não é tão eficiente quanto nos adultos e o estímulo de coagulação e fibrinólise é pior. Antes de um ano de idade, as concentrações plasmáticas dos fatores de coagulação dependentes da vitamina K (II, VII e X), as proteínas Se C e outros componentes (precalicreína, cininogênio, fator XI e fator de Hageman) são mais baixas em virtude da imaturidade hepática ${ }^{22}$. Nas cardiopatias com estado cianótico ocorre problema extra, próprio desses pacientes, em conseqüência da policitemia, diminuição no número de plaquetas, diminuição na concentração dos fatores de coagulação $V$, VII, VIII e aumento na fibrinólise ${ }^{21}$. Quando essas crianças são submetidas a CEC enfrentam ainda a desproporção entre o tamanho da máquina de CEC e seu peso, o que força uma grande hemodiluição e conseqüente diluição dos fatores da coagulação.

A aprotinina tem sido utilizada em adultos submetidos à cirurgias de grande porte e grande perda sangüínea com resultados inconclusivos ${ }^{23,24}$. Em crianças, o uso da aprotinina e outros agentes antifibrinolíticos que à primeira vista poderiam ser úteis, mostram-se controversos. Alguns estudos apresentam a ineficácia da aprotinina em pacientes pediátricos submetidos a $\mathrm{CEC}^{25}$. Enquanto outros, estudando pacientes acima de um ano de idade, com malformações cardíacas complexas, empregaram altas doses de aprotinina encontrando redução no sangramento intra-operatório ${ }^{26}$. Decididamente, em crianças abaixo de um ano, ou em pacientes operados uma única vez, o uso da aprotinina, mesmo em doses elevadas, não apresenta benefícios que o justifiquem ${ }^{25}$. Há que se observar que todos esses estudos utilizaram doses muito diversas entre si. Para a cirurgia cardíaca pediátrica a dose de aprotinina deveria ser calculada por superfície corporal em vez de mg/peso. Além disso, a aprotinina precisa ser adicionada ao volume de pré-enchimento ("prime") da máquina de CEC para compensar a hemodiluição. Se a dose plasmática for inferior a $200 \mathrm{UI} \cdot \mathrm{ml}^{-1}\left(0,03 \mathrm{mg} \cdot \mathrm{ml}^{-1}\right)$ não haverá prevenção da ativação de contato do sistema de coagulação. O mesmo raciocínio pode ser estendido aos outros antifibrinolíticos ${ }^{27,28}$.

\section{EXPOSIÇÃO TRANSFUSIONAL MÍNIMA}

Exposição transfusional mínima (ETM) é uma expressão criada para definir o sangue homólogo, ou seus derivados, provenientes de um número mínimo de doadores. Essa estratégia visa reduzir os problemas imunológicos e os riscos de infecção potencialmente maiores quando o paciente recebe sangue proveniente de um grande número de doadores. Nos pacientes pediátricos, essa técnica é bastante fácil de ser im- 
plementada, com um planejamento adequado da transfusão, haja vista os pequenos volumes a serem transfundidos. Apesar de a perda ser considerável para o paciente, o volume a ser transfundido será pequeno, comparado com uma bolsa coletora de $400 \mathrm{ml}$. Logo, será fácil administrar sangue e derivados de um único doador.

\section{HIPOTENSÃO ARTERIAL CONTROLADA}

A redução intencional da pressão sangüínea tem sido usada há muitos anos para diminuir a perda sangüínea no período intra-operatório ${ }^{29-31}$. Muitas técnicas são preconizadas para reduzir a pressão arterial, tais como: infusão contínua de vasodilatadores (nitroprussiato de sódio, nitroglicerina) ${ }^{29}$, beta-bloqueadores ${ }^{30}$, níveis profundos de anestesia inalatória $^{30,31}$, bloqueadores do canal de cálcio ${ }^{32}$ e adenosina. Nenhuma dessas técnicas encontra suporte para uso rotineiro em pacientes pediátricos, a não ser naqueles com idade maior e adolescentes. O uso de planos profundos de anestesia pode ser perigoso em virtude da depressão miocárdica, que demora a ser revertida em caso de maus resultados. Crianças abaixo de dois anos de idade têm o débito cardíaco dependente da freqüência cardíaca. O uso de beta-bloqueadores está contra-indicado nesse grupo de pacientes.

Os riscos da hipotensão arterial induzida são grandes ${ }^{31}$; portanto a relação risco/benefício deve ser avaliada para cada paciente. Idades inferiores a dois anos constituem-se em contra-indicação, bem como doenças sistêmicas com comprometimento de funções vitais. Ainda como no passado, experiência com as técnicas e familiaridade com as características dos fármacos a serem utilizados são fundamentais para o êxito ${ }^{33}$.

\section{CONCLUSÃO}

Mais uma vez se evidencia que as soluções obtidas para adultos não são aplicáveis inteiramente aos pacientes pediátricos. As medidas para reduzir o sangramento intra-operatório e a conseqüente redução na necessidade do emprego de sangue homólogo, são eficientes em pacientes adultos, porém são de longe mais invasivas, complicadas e muitas delas ineficientes nos pacientes pediátricos, notadamente naqueles abaixo de dois anos de idade.

\section{Blood Transfusion in Pediatric Patients and Strategies to Decrease it: $A$ Reevaluation}

Mário José da Conceição,TSA, M.D.

\author{
INTRODUCTION
}

Several approaches and techniques are used in adult patients to decrease or prevent both blood loss and homologous blood transfusion during surgical procedures where massive blood losses are expected ${ }^{1-3}$. Most patients are informed about blood transfusion adverse effects, especially after the advent of the risk of contamination by human immunodeficiency virus (HIV). There is also a religious faith-related problem, such as the Witnesses of Jehovah. While these blood-sparing strategies are widely used in adults, they are mostly neglected in children, as it can be seen by the few studies in the literature about the subject. Perhaps in pediatric patients, these blood-sparing techniques may not be as effective as in adults and technical limitations, as the small size of patients could limit its advantages. However, some strategies based on adult patients experiences may be used to decrease or even prevent homologous blood transfusion in some pediatric surgeries where patients have been previously selected and indications were adequately defined. In the following review, blood-sparing techniques established for adults are described and their applicability for pediatric patients is discussed.

\section{PREOPERATIVE AUTO-DONATION}

To date, the most widely accepted technique to decrease or prevent the risks of homologous transfusion is preoperative autologous blood donation, followed or not by hemodilution ${ }^{4}$. If there are sound scientific basis and practical usefulness for adults, this practice has several complicating factors which increase the risk for pediatric patients and may be described as follows:

1. Children may need sedation or anesthesia for donation and for such, inhaled anesthetics might be preferred. Propofol, thiopental and opioids should be avoided because they may trigger adverse events at re-transfusion;

2. Collection bags have to be special and smaller because traditional bags have anticoagulant solutions calculated for large adult volumes, which would be excessive for small pediatric volumes;

3. Problems with venous access may prevent auto-donation in several pediatric patients where there will be problems with adequate needle size for blood collection ${ }^{5}$.

Regardless of these complicating factors, many authors advocate auto-transfusion in children for believing that benefits overcome risks and already mentioned problems. However, due to the complexity of pediatric auto-donation, this should 
only be indicated for patients above $20 \mathrm{~kg}$ and in whom large intraoperative blood volume losses are expected ${ }^{5}$.

\section{HEMODILUTION}

Theoretically, hemodilution in pediatric patients is much easier to be performed than preoperative auto-donation. However, Bryson et al. ${ }^{6}$ have shown in a recent meta analysis that intraoperative hemodilution has not decreased the need for homologous blood. Still according to the authors, several studies included in the meta analysis have not taken into consideration basic hemodilution principles, such as: initial hematocrit above $35 \%$ and minimum tolerated hematocrit below $25 \%$. If these criteria were not considered, removed blood volume would be insufficient to establish a difference as to the need for homologous blood. Most times, these criteria cannot be adopted for children. First, in infants up to 6 month of age, hemodilution is counterindicated due to high fetal hemoglobin concentration. As it is well known, fetal hemoglobin shifts oxyhemglobin curve to the left, limiting tissue oxygen availability. Low hematocrit in this situation may lead to hypoxia and/or tissue ischemia. From 6 months to 1 year of age, there will be the so-called "physiological anemia" again counterindicating very low hematocrit for the same reasons. This way, hemodilution should only be used in children above 1 year of age. However there are few studies in this area to prove the efficacy and discuss potential problems like in adults ${ }^{6}$.

\section{INTRAOPERATIVE AUTO-TRANSFUSION}

Although good results obtained in adult patients with intraoperative auto-transfusions, decreasing losses and the need for homologous blood, such techniques cannot be directly applied to pediatric patients ${ }^{8}$.

The volume of "lost" blood is almost always too low to be collected although being high for patients' volume. Very often the blood is not even aspired because it has already been absorbed by compresses, surgical drapes of surgeons gloves themselves. Even if compresses are washed with saline, at least $50 \%$ of blood volume is lost. For the auto-transfusion machine to adequately operate, a minimum blood volume has to be washed and re-transfused. This volume is approximately $300 \mathrm{~mL}$, which may mean much more than half the volume of a $20-\mathrm{kg}$ patient. Children below this weight certainly will not tolerate $300 \mathrm{ml}$ volume loss without receiving homologous blood ${ }^{9}$. However, children above $20 \mathrm{~kg}$ may tolerate such losses. In these patients, auto-transfusion techniques may be useful. But a different problem should be raised: which is the minimum hematocrit considered "safe" for pediatric patients? Most specialized pediatric anesthesiologists do not allow hematocrit below $30 \%$, especially in patients below 1 year of age and due to the above mentioned reasons, as opposed to adults or children above $30 \mathrm{~kg}$, when values well below this may be used. However, other authors suggest using hematocrit as low as $17 \%$ in patients weighing 11 to $23 \mathrm{~kg}$ without tissue oxygenation problems ${ }^{10}$. For those authors, higher losses may be tolerated without the need for homologous blood, even by patients below $20 \mathrm{~kg}^{10,11}$. There are already auto-transfusion machines for pediatric patients, however with disadvantages still not solved by technology ${ }^{12}$. One of these machines tried to solve the problem with lower capacity of the container for drained blood from the surgical field, allowing equipment operation with $100 \mathrm{~mL}$ blood. The problem is that very often the container is not totally filled and one unit of autologous blood with unpredictable quality and hematocrit is administered. Another machine is the continuous auto-transfusion equipment which has eliminated drained blood container. Drained blood is pumped to a separation chamber with capacity of up to $30 \mathrm{~mL}$, while $0.9 \%$ saline solution is added for washing. This equipment allows the processing of blood volumes below $100 \mathrm{ml}$ and auto-transfusion in patients below $10 \mathrm{~kg}$.

In cardiac surgeries with cardiopulmonary bypass (CPB), part of the blood remaining in the CPB machine circuit may be re-transfused after filtration, thus decreasing the need for homologous blood ${ }^{13}$.

A simple solution would be direct re-transfusion of drained blood from the surgical field without washing it. However, the re-transfusion of non washed blood activates the fibrinolytic system with consequent fibrinolysis and increased blood loss ${ }^{14}$

\section{DESMOPRESSIN}

Von Willebrand's factor is critical in the beginning of clot formation, favoring adhesiveness of platelets to injured regions of the vascular endothelium. Desmopressin favors von Willebrand's factor release from endothelial reserves and increases glycoprotein receptors expression on platelets surface. This way, platelets adhesiveness to injured endothelial regions is increased. Normal dose is in general $0.3 \mu \mathrm{g} . \mathrm{kg}^{-1}$. Initially, it was used after cardiopulmonary bypass aiming at decreasing bleeding and improving blood coagulation. It has also been used preventively with the same purpose in major surgeries where massive losses are expected ${ }^{15}$. Its use in adults, however, is surrounded by controversies. For pediatric patients, desmopressin also does not add any advantage ${ }^{16}$. Not only it does not interfere with blood loss, but von Willebrand's factor dosage, in controlled studies, was the same in patients receiving or not desmopressin ${ }^{17}$. Pediatric patients do not increase the amount of von Willebrand's factor released from reserves after receiving desmopressin ${ }^{17}$. it seems that this fact is related to the surgical procedure itself, the stimulation of which releases maximum von Willebrand's factor in a way that there are no extra releases with desmopressin.

\section{ANTIFIBRINOLYTIC AGENTS}

Currently, antifibrinolytic agents are used preventively to decrease intraoperative bleeding in patients submitted to surgeries with CPB ${ }^{18,19}$. Some studies have shown significant blood loss decrease when aprotinin or lysin analogs 


\section{A REEVALUATION}

(transexamic and epsilon-amino-caproic acids) are used ${ }^{20}$. These studies, however, were performed with adult patients submitted to cardiac surgery with CPB. During CPB, there is in fact an abnormal activation of coagulation and fibrinolysis systems. Coagulation is prevented with heparin however fibrinolysis is neglected. Since during CPB there is plasminogen activator factor stimulation, fibrinolysis is started with increased bleeding. In pediatric patients this seems to work in the opposite direction ${ }^{21}$. The balance between coagulation and fibrinolysis is more unstable and subject to exogenous stimulation. Hemostasis in pediatric patients is not as efficient as in adults and coagulation and fibrinolysis stimulation is poorer. Before one year of age, plasma concentrations of vitamin K (II, VI and X) dependent coagulation factors, of $S$ and $C$ proteins and of other components (prekallikrein, kininogen, factor XI and Hageman's factor) are lower due to liver immaturity ${ }^{22}$. In heart diseases with cyanosis there is an extra problem, typical of these patients as consequence of polycythemia, decreased number of platelets, decreased concentration of coagulation factors $\mathrm{V}$, VII and VIII, and increased fibrinolysis ${ }^{21}$. When these children are submitted to CPB they also face the disproportion between the size of the CPB machine and their weight, forcing major hemodilution and consequent coagulation factors dilution.

Aprotinin has been used in adults submitted to major surgeries and major blood losses, however with inconclusive results ${ }^{23,24}$. In children, aprotinin and other antifibrinolytic agents which could be useful at the first sight, are controversial. Some studies have shown the inefficacy of aprotinin in pediatric patients submitted to $\mathrm{CPB}{ }^{25}$, while others, studying patients above 1 year of age with complex heart malformations, have used high aprotinin doses and have observed decreased intraoperative bleeding ${ }^{26}$.

Definitely in children below 1 year of age, or in patients operated on just one time, aprotinin, even in high doses, has no benefits justifying its use ${ }^{25}$. It has to be mentioned that all these studies have used very different doses. For pediatric cardiac surgery aprotinin dose should be calculated by body surface and not by $\mathrm{mg} /$ weight. In addition, aprotinin has to be added to pre-filling (prime) volume of the CPB machine to compensate hemodilution. If plasma dose is below 200 UI. $\mathrm{mL}^{-1}\left(0.03 \mathrm{mg} \cdot \mathrm{mL}^{-1}\right)$ there will be no prevention of coagulation system contact activation. The same reasoning could be applied to other antifibrinolytic agents ${ }^{27,28}$.

\section{MINIMUM TRANSFUSION EXPOSURE}

Minimum transfusion exposure (MTE) is an expression created to define homologous blood or its blood products coming from a minimum number of donors. This strategy would be aimed at decreasing immune problems and potentially higher infection risks when patients receive blood from a high number of donors. This technique has been widely implemented in pediatric patients with an adequate transfusion planning due to the low volumes to be transfused. Although the loss is considerable for the patient, transfused volume will be low as compared to $400 \mathrm{ml}$ collection bags. Hence, it will be easy to give blood and blood products from a single donor.

\section{CONTROLLED ARTERIAL HYPOTENSION}

Intentional blood pressure decrease has been used for a long time to decrease intraoperative blood losses ${ }^{29-31}$. Several techniques are preconized to decrease blood pressure, such as: continuous infusion of vasodilators (sodium nitroprusside, nitroglycerin) ${ }^{29}$, beta-blockers ${ }^{30}$, deep inhalational anesthesia levels ${ }^{30,31}$, calcium channel blockers ${ }^{32}$ and adenosine. None of them have support for routine use in pediatric patients, unless in older children and adolescents. Deep anesthesia may be dangerous due to myocardial depression which takes time to be reverted in case of poor results. Children below 2 years of age have cardiac output dependent on heart rate. Beta-blockers are counterindicated in this group of patients. Induced hypotension risks are major ${ }^{31}$, so risk/benefit ratio should be evaluated in a case-by-case basis. Ages below 2 years are a counterindication, as well as systemic diseases with vital functions involvement. As in the past, experience with techniques and familiarity with drugs to be used are critical success factors ${ }^{33}$.

\section{CONCLUSION}

Once more it has been shown that adult solutions are not totally applicable to pediatric patients. Methods to decrease intraoperative bleeding and the need for homologous blood are effective for adults, but are by far more invasive, complicated and several of them are ineffective for pediatric patients, especially those below 2 years of age.

\section{REFERÊNCIAS - REFERENCES}

01. Curcio K, Souza MLM - Sangue total e derivados - conceitos e critérios de uso. Rev Bras Anestesiol, 1993;43:(Supl16):1-9 .

02. Macuco MV, Carrenho JMX, Zambonato JF - Efeito imediato da hemodiluição normovolêmica aguda pré-operatória sobre o hematócrito em pacientes adultos. Rev Bras Anestesiol, 1998;48:475-484.

03. Miyoshi E, Carmona MJC, Uema E et al - Hemodiluição aguda perioperatória com hidroxietilamido a $6 \%$ em cirurgia cardíaca: repercussões hemodinâmicas e sobre o transporte de oxigênio. Rev Bras Anestesiol, 2000;50:26-31.

04. Forgie MA, Wells PS, Laupacis A et al - Preoperative autologous donation decreases allogeneic transfusion but increases exposure to all red blood cell transfusion: results of a meta-analysis. International Study of Perioperative Transfusion (ISPOT) Investigators. Arch Intern Med, 1998;158:610-616.

05. Mayer MN, Montalembert M, Audat F et al - Autologous blood donation for elective surgery in children weighing $8-25 \mathrm{~kg}$. Vox Sang, 1996,70:224-228.

06. Bryson GL, Laupacis A, Wells GA - Does acute normovolemic hemodilution reduce perioperative allogeneic transfusion? A meta-analysis. The international study of perioperative transfusion. Anesth Analg, 1998;86:9-15. 
07. Weiskopf RB - Efficacy of acute normovolemic hemodilution assessed as a function of fraction of blood volume lost. Anesthesiology, 2001;94:439-446.

08. Huet C, Salmi LR, Fergusson D et al - A meta-analysis of the effectiveness of cell salvage to minimize perioperative allogeneic blood transfusion in cardiac and orthopedic surgery. International study of perioperative transfusion. Anesth Analg, 1999;89:861-869.

09. Mazzarello G, Lampugnani E, Carbone M et al - Blood saving in children. Anaesthesia 1998;53:(Suppl2):30-32.

10. Aly Hassan A, Lochbuehler H, Frey L et al - Global tissue oxygenation during normovolaemic haemodilution in young children. Paediatr Anaesth, 1997;7:197-204.

11. Booke $\mathrm{M}$, Van Aken $\mathrm{H}$ - What is the minimum weight required to effectively perform intraoperative autotransfusion in small children - an in vitro investigation. Anaesth Intensive Care, 2001; 29:74-77.

12. Booke M, Hagemann $\mathrm{O}$, Van Aken $\mathrm{H}$ et al - Intraoperative autotransfusion in small children: an in vitro investigation to study its feasibility. Anesth Analg, 1999;88:763-765.

13. Friesen RH, Tornabene MA, Coleman SP - Blood conservation during cardiac surgery: ultrafiltration of the extracorporeal circuit volume after cardiopulmonary bypass. Anesth Analg 1993;77:702-707

14. Riou B, Arock M, Guerrero M et al - Haematological effects of postoperative autotransfusion in spinal surgery. Acta Anaesthesiol Scand, 1994;38:336-341.

15. American Society of Anesthesiologists Task Force: Practice Guidelines for Blood Component Therapy. Anesthesiology, 1996;84:732-747

16. Lethagen S - Desmopressin - a haemostatic drug: state-of-the-art review. Eur J Anaesthesiol, 1997;14:(Suppl14): $1-9$.

17. Laupacis A, Fergusson D - Drugs to minimize perioperative blood loss in cardiac surgery: meta-analyses using perioperative blood transfusion as the outcome. The international study of perioperative transfusion investigation. Anesth Analg, 1997;85:1258-1267.

18. Pereira JCD, Auler Jr JOC - Antifibrinolíticos em cirurgia cardíaca. Estado atual. Rev Bras Anestesiol, 1994;44:205-210.

19. Levi M, Cromheecke ME, de Jonge E et al - Pharmacological strategies to decrease excessive blood loss in cardiac surgery: a meta-analysis of clinically relevants endpoints. Lancet, 1999;354:1940-1947.

20. Dalmau A, Sabate A, Acosta F et al - Tranesaxamic acid reduces red cell transfusion better than epsilon-aminocaproic acid or placebo in liver transplantation. Anesth Analg, 2000;91:29-34.

21. Reid RW, Burrows FA, Hickey P - Anesthesia for Children Undergoing Heart Surgery, em: Coté CJ, Ryan JF, Todres ID et al - A Practice of Anesthesia for Infants and Children, $3^{\text {rd }}$ Ed, Philadelphia, WB Saunders Company, 2001;391-413.

22. Andrew M, Paes B, Johnston M - Development of the hemostatic system in the neonate and young infant. Am J Pediatr Hematol Oncol, 1990;12:95-104.

23. Soilleux H, Gillon MC, Mirand A et al - Comparative effects of small and large aprotinin doses on bleeding during orthotopic liver transplantation. Anesth Analg, 1995;80:349-352.

24. Porte RJ, Molenaar IQ, Begliomini B et al - Aprotinin and transfusion requirements in orthotopic liver transplantation: a multicentre randomised double-blind study. Lancet, 2000;355:1303-1309.

25. Davies MJ, Allen A, Kort $\mathrm{H}$ et al - Prospective, randomised, double-blind study of high-dose aprotinin in pediatric cardiac operations. Ann Thorac Surg, 1997;63:497-503.
26. Carrel TP, Schwanda M, Vogt PR et al - Aprotinin in pediatric cardiac operations: a benefit in complex malformations and with high-dose regimen only. Ann Thorac Surg, 1998;66:153-158.

27. Williams GD, Bratton SL, Riley EC et al - Efficacy of epsiIon-aminocaproic acid in children undergoing cardiac surgery. J Cardiothorac Vasc Anesth, 1999;13:304-308.

28. Reid RW, Zimmerman AA, Laussen PC et al - The efficacy of tranexamic acid versus placebo in decreasing blood loss in pediatric patients undergoing repeat cardiac surgery. Anesth Analg, 1997;84:990-996.

29. Grando TA, Puricelli E, Chiao IU et al - Hipotensão induzida e controlada pelo halotano e nitroprussiato de sódio na cirurgia ortognática. Rev Bras Anestesiol, 1990;40:325-330.

30. Vieira JL, Katayama M - Hipotensão induzida com bloqueadores alfa e beta1 e halogenados: comparação entre enflurano, halotano e isoflurano em rinoplastias. Rev Bras Anestesiol, 1992;42:201-206

31. Grando TA, Puricelli E, Ishiguro RM et al - Avaliação do risco de complicações em duas técnicas de hipotensão controlada em cirurgi ortognática. Rev Bras Anestesiol, 1996;46:1-7.

32. Tobias JD, Hersey S. Mencio GA et al - Nicardipine for controlled hypotension during spinal surgery. J Pediatric Orthop, 1996;16:370-373.

33. Eckenhoff JE - Deliberate hypotension. Anesthesiology, 1978;48:87-88

\section{RESUMEN}

Conceição MJ - Transfusión Sanguínea en Niños y los Métodos para Evitarla: Una Reevaluación

JUSTIFICATIVA Y OBJETIVOS: Muchas medidas y técnicas son utilizadas, en pacientes adultos, en la tentativa de reducir, o evitar, tanto la pérdida sanguínea como la administración de sangre homólogo durante actos quirúrgicos para los cuales se esperan grandes perdidas en la volemia. Entretanto, las estrategias para evitar la utilización de sangre homólogo en pacientes adultos son largamente utilizadas, en los pacientes pediátricos son negligenciadas. Quizás eso se deba al hecho de que en niños esas técnicas pueden no ser tan útiles cuanto en los adultos, además de los problemas técnicos propios del tamaño de los pacientes. El objetivo de esa revisión fue reevaluar las técnicas para reducir la necesidad de transfusión de sangre homólogo en adultos y discutir su utilización en pacientes pediátricos.

CONTENIDO: Por medio de la pesquisa bibliográfica se presentan las estrategias más frecuentes para disminuir, o mismo evitar, transfusión de sangre homólogo durante actos quirúrgicos en los cuales se esperan grandes perdidas volémicas. Como todos los métodos conocidos fueron desarrollados para pacientes adultos, se proyecta, a partir de aquí, reevaluandose esos métodos, técnicas y fármacos, una línea de acción mirando su aplicabilidad a los pacientes pediátricos.

CONCLUSIONES: Mas una vez queda patente que las soluciones obtenidas para adultos no son aplicables enteramente a los pacientes pediátricos. Las medidas para reducir el sangramiento intra-operatorio y la consecuente reducción en la necesidad del uso de sangre homólogo son eficientes en pacientes adultos, no obstante son de lejos más invasivas, complicadas y muchas de ellas ineficientes en los pacientes pediátricos, notadamente en aquellos menores de dos años de edad. 